\title{
The impact of climate change on community, culture, and gender in Central Kalimantan
}

\author{
Sari Marlina ${ }^{1 *}$, Bambang Supriyono Lautt ${ }^{2}$, Aswin $\mathrm{Usup}^{3}$, and Revi Sunaryati ${ }^{4}$ \\ ${ }^{1}$ Environmental Engineering Study Program, School of Environmental Sciences, Postgraduate School \\ of Palangkaraya University, Palangkaraya, 73111, Indonesia. \\ ${ }^{2} \mathrm{Head}$ of Environmental Sciences Doctoral Program in Palangkaraya University, Palangkaraya, \\ 73111, Indonesia. \\ ${ }^{3}$ Head of LPPM Palangkaraya Univesity, Palangkaraya University, Palangkaraya, 73111, Indonesia. \\ ${ }^{4}$ Lecturer of Economics Social, Faculty of Agriculture, Palangkaraya University, Palangkaraya, \\ 73111, Indonesia.
}

\begin{abstract}
The impacts of climate change in the last decade are tropical storms, rising sea levels, and forest fires. These impacts damage human health, natural resources, and gender equality. This study aimed to identify the effects of climate change in the community, cultural development, and gender roles in addressing climate change in Central Kalimantan. This study used a cross-sectional design with questionnaires. Data collection was carried out using interview and observation techniques with a purposive sampling method. Interviews were conducted with 30 respondents in each district. The results of the study showed that the community has long felt climate change in Central Kalimantan. Still, they do not yet understand that changes in rainfall and temperature patterns reduce environmental conditions and forests' function to support daily life. The openness of access to natural resources for women gives the responsibility of maintaining families during climate change, for example, utilizing plants to be used as weaving material in managing wet and dry forest ecosystems that increase deforestation rates. In the future, stakeholders, including regional government, will issue policies that protect women's rights and interests to ensure that women get the same access and benefits related to information and decision-making, especially in natural resources management.
\end{abstract}

\section{Introduction}

Climate change and global warming have broad impacts on global, national, and local levels. Effects that have emerged in the last decade are tropical storms, changes in weather patterns, floods, landslides, north, and south polar ice cap melting, rising sea levels, drought, and forest fires. These impacts damage the quality of the environment and

* Corresponding author: $\underline{\text { sari007marlina@gmail.com }}$ 
endanger human health, food security, economic development activities, natural resources management, and infrastructure.

As an archipelago state, Indonesia is very vulnerable to climate change. The vast natural disasters in Indonesia, such as floods, landslides, droughts, storms, are evidence of vulnerability. The National Disaster Management Authority (BNPB) showed that in 19822012 there were 4121 times of flood, 1983 times of landslide, 1903 times of storm, and 1414 times of drought, as an impact of the climate change phenomenon [3]. During the high need for adaptation, Indonesia declared a commitment to reduce emissions to $26 \%$ by 2020 on its efforts or $41 \%$ with international assistance. President SBY stated it at an international negotiation meeting for climate change, COP 15 in Copenhagen, Denmark. With an emission reduction of $26 \%$, it is expected that $14 \%$ of the forestry sector.

Development programs adjust efforts to climate conditions caused by climate change due to global warming. The gender-responsive climate change impact prevention strategy is carried out by positioning climate change adaptation action programs in various fields to improve family resilience. At present, gender considerations have not been explicitly stated in different climate change policies [18]. The study on gender differences and public opinion on climate change in America [9]. A survey of adaptation patterns of men and women in 3 (three) types of livelihoods (farmers, fishermen, and charcoal production) and the adaptive capacity of women to water scarcity due to climate change $[6,13]$.

Some areas have international projects that discuss climate change issues in Central Kalimantan. Most women are not involved in project planning, and it is infrequent for groups of women to be asked for opinions or input related to projects in the region. The role of women is powerful in natural resources management in the area. The daily activities of women include finding wood and catching fish and looking for medicinal plants in the forest. Any problems in the forest have a significant impact on life, both directly and indirectly. Some sectors have begun to be affected by climate change, this can be seen from the lack of water during the dry season but flooding during rainy season. The forestry, agriculture, and plantation sectors are also affected by the climate change phenomenon, and this is due to the uncertainty of the rainy and dry seasons so that the development of each commodity in various sectors is disrupted [1].

The lack of publication related to the impact caused by climate change on women, encourage the researcher to research so that it can become a necessary foundation in making policies for the protection of gender, especially women and children in this region. This problem is focused on the impact of climate change on several scopes, namely community, culture, and gender. The purpose of this study was to identify the effects of climate change in the community, cultural development, and gender role in addressing climate change in Central Kalimantan.

\section{Method}

\subsection{Time and location of study}

This study used a cross-sectional design with questionnaires filled out by communities in several villages in several Regency and District in Central Kalimantan.

\subsection{Data collection technique}

The sample population in this study is the village community in 2 (two) districts, namely Pulang Pisau Regency and Kapuas Regency. Examples are distinguished by sex for each district as many as 30 respondents consisting of 10 (ten) men and 20 (twenty) women. This 
study used primary and secondary data [20]. Primary data were obtained by filling in structured questionnaires on (1) Individual characteristics in the form of education, employment, and income; (2) Perception of community on culture and gender role in climate change adaptation in Central Kalimantan.

Data collection technique used were:

a. Data collection was carried out using interview and observation techniques with a purposive sampling method. Purposive sampling is the intentional selection of informants based on their ability to elucidate a specific concept, theme, or phenomenon. Purposive sampling represents a group of different non-probability sampling techniques. Interviews were conducted with 30 respondents in each district.

b. Direct and live-in observations to directly observe the climate change situation on the condition of community, culture, and gender and

c. Literature study related to climate change policy both in national literature and local literature.

d. Women focus group discussion (FGD) to map the impact and influencing factors in the village. In addition to mapping, the FGD was conducted to discuss the effects of climate change on women.

e. Village focus group discussion to discuss the role of women in the region related to the impacts caused by climate change.

f. To obtain in-depth information, interviews, and in-depth FGDs were conducted with community leaders, women, traditional leaders, women leaders, NGOs, and government.

The data used were rainfall data, temperature data, and economic growth data [11]. Secondary data used were obtained from relevant agencies, namely the Central Statistics Agency of Central Kalimantan (online and print publications) and Central Kalimantan Development Planning Agency (online publications). This study used descriptive analysis. Descriptive analysis is carried out to determine the value of independent variables, either one or more variables without making comparisons, or connecting with other variables [16]. Descriptive analysis was used to analyze the role of women's life expectancy, average education duration of women, and the level of participation in climate change adaptation in Central Kalimantan.

\section{Results and discussion}

\subsection{Climate change in Central Kalimantan}

Conditions and natural resources influence the life of Central Kalimantan community. Besides, life is also supported by the geographical location between three other provinces, namely, in the north, it borders East Kalimantan Province and West Kalimantan Province, in the east, it borders East Kalimantan Province and South Kalimantan Province, in the south, it borders the Java Sea, and in the west, it borders West Kalimantan Province. It is located from $0^{\circ} 45$ 'North to $3^{\circ} 30^{\prime}$ South and $111^{\circ}$ East. The area of Central Kalimantan Province is 153,564 sq.km, and due to the regional expansion, which used to be only 6 Regencies or Cities, now Central Kalimantan Province has 14 Regencies or Cities. With all the interests of each region, such as development, especially in forests and land clearing for community needs, it causes a reduction in the potential of natural resources both in terms of quantity and quality. In 2019, based on the observation of 5 meteorological stations, May had the highest number of rainy days which can be seen in Figure 1. 


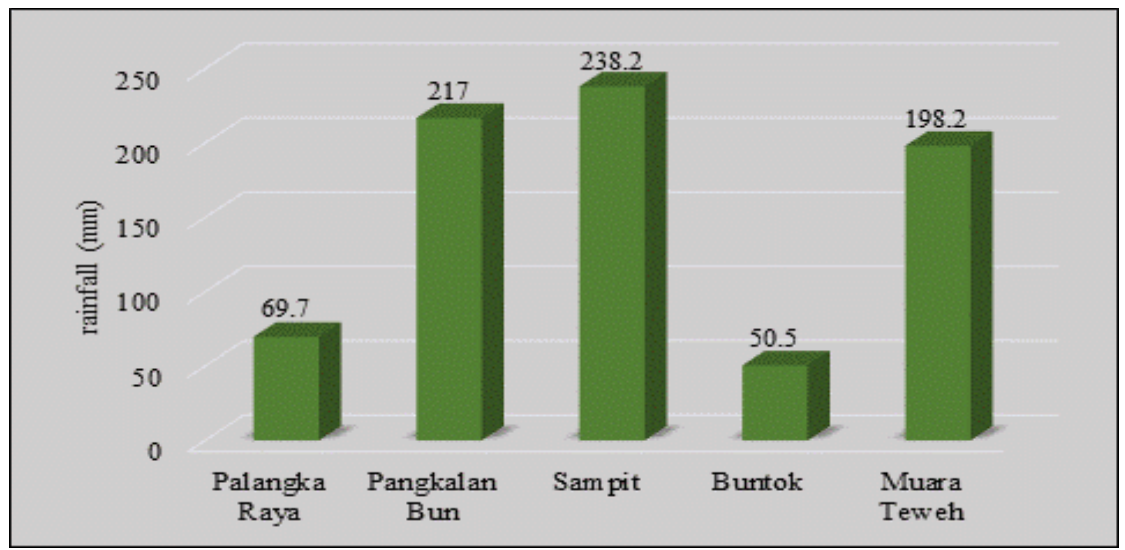

Fig. 1. Rainfall and monthly rainy days based on Central Kalimantan Meteorology, Climatology, and Geophysical Agency [2].

Central Kalimantan Province, with the capital of Palangkaraya, is located $16 \mathrm{~m}$ above sea level. This province has a tropical climate and a high amount of rainfall throughout the year. This also applies to the driest month. Based on Kopper-Geiger, the climate classification throughout the year is Af. The average annual temperature was $26.7^{\circ} \mathrm{C}$ or $80.0^{\circ} \mathrm{F}$. Annual rainfall reached $2598 \mathrm{~mm}[3]$.

\subsection{Understanding of community on climate change}

The climate and rainfall graphs above indicate a disturbance in the atmospheric layer, both at local and regional scales, so that it can affect rainfall patterns in Central Kalimantan and surrounding areas throughout the year. The impact of climate change is susceptible to developments in various sectors. The index can be seen in Figure 2 in 2014-2020.
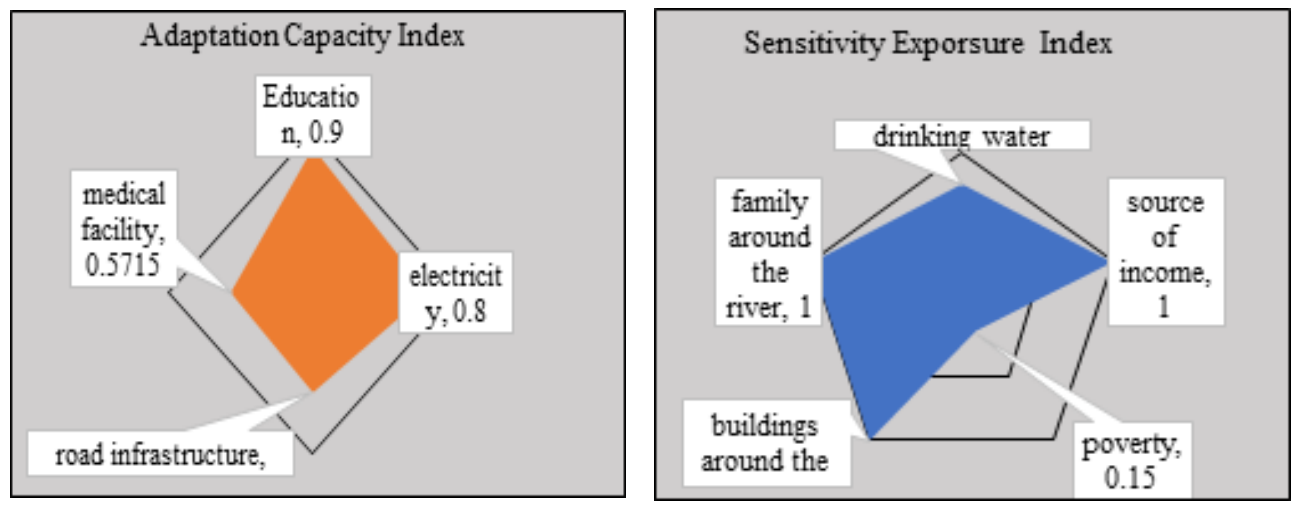

Source. BPS (2020) and www.indonesia.climatewatchdata.org, processed

Fig. 2. Climate vulnerability and adaptation capacity in Central Kalimantan

Some communities do not understand that the uncertain weather conditions due to increased climate change, but they realize that the conditions of the season have changed. The loss can see the impact of climate change of forest cover in Central Kalimantan both in peatlands and non-peatlands which can be seen in Figure 3 below. 


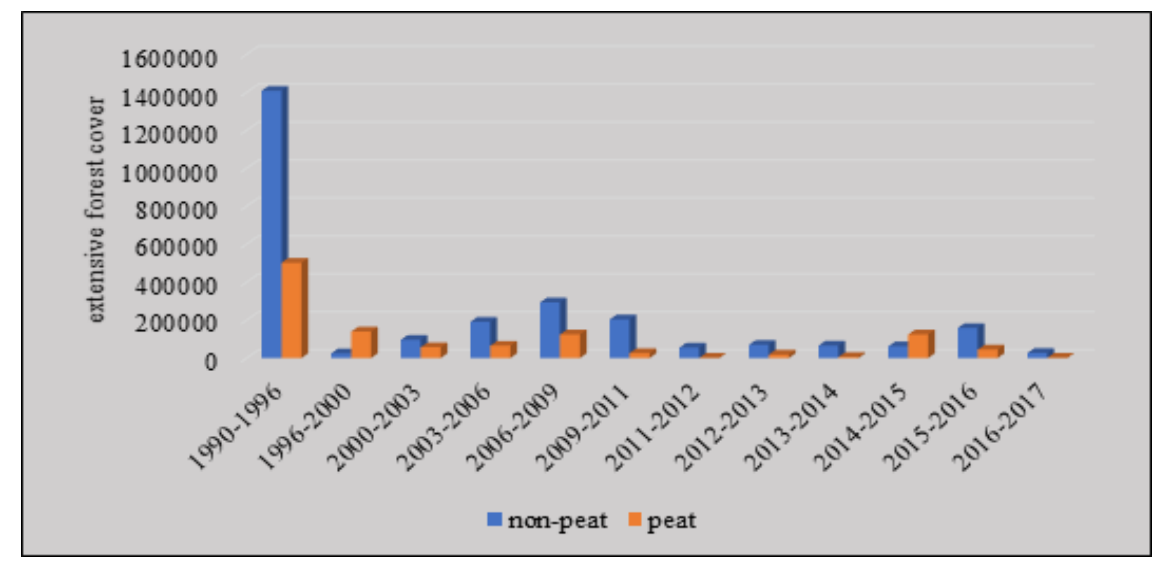

Source. BPS (2020) and www.indonesia.climatewatchdata.org, processed

Fig. 3. The lost area of forest cover in Central Kalimantan

Farmers in Pulang Pisau Regency and Kapuas Regency do not use calendars to determine the growing season. Farmers determine the growing season depending on the weather at a particular time [17] [19]. In Jabiren Raya District in Pulang Pisau Regency, the coastal community observes that there is a high wave of water, so most fish are no longer on the surface. This begins with the increase so that the seawater gets hotter. Seasonal changes affect the vegetation conditions in Sebangau National Park and Tanjung Puting National Park. The community observed that the plant ecosystem in the village and the area around the National Park changed significantly.

Based on the discussion results, the community stated that there is a climate change and an increase in air temperature in the village. The dynamics of natural resource management on economic sustainability, environmental sustainability, and social and cultural sustainability have significant development [8]. This shows that understanding of sustainable development has not yet become part of the daily life practices of development practitioners who care about the environment and social culture.

This situation is a threat that can cause flooding, burning peatlands, and reduced biodiversity that has high economic value, such as medicinal plants abundant in tropical forests and peatlands that store a lot of carbon to reduce the threat of global warming [14]. Fishermen also felt the impact of seasonal changes. Fishermen feel that high waves occur more frequently, and the number of fish near the sea level decreases. This affects fish catches so that income declines.

Peatland degradation causes other problems that will arise in the future. Cut down and drained peatlands will be sources of hotspots so that the worst possibility will occur on peatlands. The current climate change is a result of the loss of peat forests, resulting in a longer dry season and increased hotspots on peatlands during the dry season. The 2015 forest and land fire disaster is the worst history of forest fires in Indonesia.

Peatlands in Central Kalimantan, in a more specific context, Central Mantangai village has a peat ecosystem whose use is not according to regulations. The limited community access to forest and land management indirectly impacts the vulnerability of ecosystems and socio-economic life. Rice fields that are not used by the community become abandoned and become shrubs. The results of interviews with several community village representatives showed other impacts of seasonal and extreme climate changes that occur every year in Mantangai, namely the agricultural sector is very sensitive to seasonal changes, as well as the conditions of the waters, seas and agricultural systems that show a 
decrease in quality due to climate change or season variations. Community life has also been affected especially by those who rely on agricultural and fishery products.

\subsection{Impact of climate change on culture and gender}

Based on the rainfall and temperature graphs in Figure 1 and Figure 2, it can be seen that both slow and extreme seasonal changes have a direct impact on inland and coastal communities. Adaptation to climate change can begin with the willingness of oneself to adapt to a changing environment.

In Pulang Pisau Regency and Kapuas Regency, the community still utilizes natural resources. The primary source of income comes from small-scale agriculture, such as planting corn, rice, and vegetables in dry land and hilly fields. They still use shifting cultivation, but they also plant crops in the surrounding fields regularly. The community collects a lot of forest products, such as wood for building houses, firewood, bamboo, rattan, leaves, medicinal plants, and many others. Fish is an important part of the daily menu. There are a number of boats with diesel engines that are used to travel to places far away in the forest. The community raises chickens and goats and hunts other wild animals in the forest. Logging provides a source of income. Wood can be transported in rivers.

Women can attend meetings but do not actively participate. In general, women are responsible for providing daily food to the family. Men are expected to get cash to finance expenditures on education, health, transportation, clothing, and household assets. Women stay home to feed their families with agricultural produce, while men migrate to cities or other provinces to find more decent work. A brief description of the use of gender-sensitive resources and deforestation of natural resources in forests can be seen in Table 1.

Table 1. Utilization of gender-sensitive resources and prevention strategies.

\begin{tabular}{|c|c|c|c|}
\hline No. & Problem & Men & Women \\
\hline 1. & $\begin{array}{c}\text { Natural resources } \\
\text { and its use }\end{array}$ & $\begin{array}{c}\text { Medicinal plants, } \\
\text { trees, wood and fruits } \\
\text { for daily use, for } \\
\text { food, and for sale }\end{array}$ & $\begin{array}{c}\text { Firewood, rattan, young edible topmost, } \\
\text { and Purun. They are mostly used for } \\
\text { handicrafts, family consumption, and for } \\
\text { sale }\end{array}$ \\
\hline 2. & $\begin{array}{c}\text { Changes in the } \\
\text { quantity and } \\
\text { existence of } \\
\text { natural resources }\end{array}$ & $\begin{array}{c}\text { There are still natural } \\
\text { resources that can be } \\
\text { utilized but have a } \\
\text { very long distance }\end{array}$ & $\begin{array}{c}\text { The distance to obtain natural resources is } \\
\text { increasingly far but the amount is getting } \\
\text { smaller }\end{array}$ \\
\hline 3. & Problem solving & $\begin{array}{c}\text { Reforestation and } \\
\text { planting of rare } \\
\text { species for local } \\
\text { needs and food }\end{array}$ & $\begin{array}{c}\text { Efforts to plant specific types of plants in } \\
\text { the yard so productivity can increase }\end{array}$ \\
\hline 4. & $\begin{array}{c}\text { Suggestions for } \\
\text { the community } \\
\text { building a mindset of } \\
\text { sustainable natural } \\
\text { resource } \\
\text { management }\end{array}$ & $\begin{array}{c}\text { Stakeholder interaction by empowering } \\
\text { local communities in building the capacity } \\
\text { of agriculture and weaving }\end{array}$ \\
\hline
\end{tabular}

Source. FORCLIME, processed

Gender-responsive is consistent and systematic attention to the differences between women and men in the community by removing structural and cultural barriers to achieve gender equality [5]. While gender issue is a condition that shows the gap between men and women or gender inequality. This gender inequality condition is obtained by comparing the expected condition and condition as it should. 
There are several opportunities to get cash income. Men, especially young people, migrate to bigger cities like Banjarmasin and its surroundings. Dependence on remittances from workers cannot be assessed. Therefore, there are more adult women than adult men in this village. The village leaders are dominated by men who serve as head of the village, head of customary law, and head of village security. The utilization of non-timber forest products (NTFPs) such as rattan and bamboo is dominated by women who produce handicrafts and weaved cloth. Reproductive and women dominate household activities, such as collecting firewood, cleaning the house, washing clothes, cooking, caring for children, and caring for the elderly and sick people. Men are less involved.

Gender-sensitive natural resources include rights and responsibilities, which can be divided into four domains as follows, 1) Control over currently defined resources. 2) Access to resources (de facto and de jure, access exclusivity, distribution of primary or secondary access), 3) Utilization of gender-sensitive natural resources (as inputs, products, assets, subsistence, and commercial use), 4) Responsibilities to obtain and or manage resources for families and communities [15]. The women farmer stated that two land management errors had been made in Peatland Village, namely Peatland Drying, by making canals with heavy equipment and repeated burning to convert wet peatlands into dry peatlands to make them easy to plant [7].

In Kapuas, some men take care of their children while their wives work in the fields or outside the village. Social activities, such as religious gatherings and community development are both attended by women and men. Women are more involved in the empowerment of family welfare, handicraft and weaving activities, and cooperatives. Meetings related to natural resources management, such as the Land Use Planning Meeting, are dominated by men.

\subsection{Changes in gender role}

The family structure in a community is a source of data, which a child uses to form gender role stereotypes. Systems in family structures such as patrilineal or matrilineal will play a role in determining the roles and positions of men and women in the community [12]. Gender roles are formed by a culture that starts in the family, where children observe differences in behavior among family members. Thus, the perception of a role starts with the behavior forming in the family. Reconstruction of the gender role can be seen from the social response to the decline in agricultural production and the reduction of peatland agricultural land due to fires caused by changes in temperature and rain patterns. The shift in gender roles can be seen as follows.

a. Reproductive activities are still dominated by women based on community norms such as childbirth, parenting, cooking, cleaning the house, washing clothes. Respondents stated that before going to the field on peatland, they must first finish work at home. Women also sometimes bring and care for their children by bringing to the farm.

b. Women have a better gender perspective than men in gender roles in domestic work and public and social work. This shows that women are more flexible in implementing gender roles in the domestic and public sectors, and tend to have perceptions of gender roles that can be changed. Although some roles in the family (domestic) are perceived as neutral, which is permissible for men and women, there is still strong segregation in perceiving functions in the family (domestic roles).

\subsection{Impact of gender role changes on vulnerability of women}

The he uncertain change in temperature and rainfall indicates an imbalance between men and women in facing changes in gender roles. 
a. Negative labeling is addressed to women in managing agricultural and plantation lands which are still underestimated because they are unable and not fit to do heavy work. This is based on the physical abilities of women and men, which are different.

b. Marginalization, this is usually considered as the economic impoverishment of women. This happens in the management of agricultural, natural resources on peatlands. Women who work as farmworkers generally have lower incomes compared to men despite having the same productive workload.

c. Dual responsibility, climate change in Central Kalimantan also directly impacts on gender development. The impact of climate change on women occurs in all aspects, for example, food, environment, energy, health, social, culture, and economy.

Climate change has an impact on crop failure in agricultural land, so the results are far from expectations. The women tend to have to spend more time looking for household food supply, and this increases agricultural work where they also have to take care of children in the fields. Whereas men are more likely to be considered not worthy of replacing the work of women such as caring for children and so on. The decision-making by women at Pulang Pisau Regency and Kapuas Regency at the household level can be seen in Table 2.

Table 2. The gender roles in household-scale decision making

\begin{tabular}{|c|c|c|}
\hline No. & $\begin{array}{c}\text { Household-scale decision } \\
\text { making }\end{array}$ & $\begin{array}{c}\text { Gender role and decision- } \\
\text { making }\end{array}$ \\
\hline 1. & $\begin{array}{c}\text { Household budget for various } \\
\text { needs and daily needs }\end{array}$ & $\begin{array}{c}\text { Decided by women with the } \\
\text { participation of men who make a } \\
\text { living }\end{array}$ \\
\hline 2. & $\begin{array}{c}\text { Health, education, household } \\
\text { needs, future savings, clearing } \\
\text { and management of agricultural } \\
\text { land }\end{array}$ & Decided together \\
\hline 3. & $\begin{array}{c}\text { Cultivation of short-term } \\
\text { seasonal plants and search for } \\
\text { firewood }\end{array}$ & $\begin{array}{c}\text { Decided by men with the } \\
\text { contribution of women }\end{array}$ \\
\hline
\end{tabular}

Most women explained that conditions due to environmental and ecosystem changes of peat (wetlands) and dry land occur quickly. Many children are witnessing changes in the peat ecosystem, which has a reduced function and purpose. Regulations on land burning were issued since peatland fires in 2015. As a result of these regulations, most agricultural land cannot be cultivated, and farmers believe that land burning is an effective way of managing rice farming in peat ecosystems [10]. The anticipation of climate change is mostly performed as a mitigation measure for climate change, which is very important, but the impact is very influential on women and children. Thus, adaptation requires the care and attention of all interested parties, both the government, regional governments, nongovernmental organizations, and international institutions.

Women experience significant obstacles on their capacity to adapt to the impacts of climate change in the present and in the future [4], so it is necessary to have a unique strategy in promoting women in climate change adaptation. Adaptation needs and priorities are grouped into 3 (three) aspects, namely: (1) comfort of residence, (2) easy access to climate change and impact information, health services, and transportation access, (3) selection of livelihoods by increasing technical knowledge and availability of natural resources for food diversification, local assistance, and counseling for community villages [4].

The impact caused by climate change varies in each country as well as socio-economic strata, age, and gender. Based on the above explanation, strategies that can be taken as a 
gender-based adaptation to climate change in the peat ecosystem at the study site, namely Central Kalimantan is one of the provinces in the peat hydrological area. Several groups of women in the discussions conducted in these villages came with school-age children so that access to education (schools) was one of the problems that had to be solved especially in the wetlands which at that time could only be accessed using a small boat. In reproductive roles, women are responsible for most of the roles in caring for the family and taking care of the house and yard. For productive roles, women are involved in the main family labor, both in the management of peatlands and post-harvest processing. While in the role of social community, various sacred and religious ritual activities continue to live with the role of women who actively carry out these activities.

Groups of women in Pulang Pisau and Kapuas play a significant role in productive work and carrying out social roles. Purun weaving is a hereditary skill in which results are sold to meet daily needs. Besides, women also process fish catches in swamps to sell for living needs. The close relationship between the role of women and nature greatly influences sustainable natural resources management so that the functions and benefits can be felt in the futur.

\section{Conclusion}

Interactions between men and women with nature differ depending on access and control in the existing ecological order, as an impact of gender-responsive social and cultural roles. Access to natural resources in Pulang Pisau Regency and Kapuas Regency in a wetland and dryland ecosystem is differentiated by gender. This difference in access is also seen in participatory activities in terms of decision-making to meet everyday life in determining the household budget, looking for firewood, lepironia weaving, meeting daily needs, and planting the land with short-term vegetable crops. The large number of men in the village who go abroad to look for new sources of income encourages women to become heads of households who certainly function as decision-makers on a household scale. The openness of access to natural resources for women gives the responsibility of maintaining families during climate change, for example, utilizing lepironia plants to be used as weaving material in managing wet and dry forest ecosystems that increase deforestation rates. Further studies are suggested to examine differences in gender equality in addressing climate change on other regencies in Central Kalimantan Province, to compare some of the specific problems experienced by women in the socio-cultural field and fulfillment of life needs. Stakeholders, including local and central government, are expected to issue effective policies that protect the rights and interests of women to get the same access and benefits related to information and decision making in managing regional natural resources and minimizing victims of natural disasters, especially for women and children.

\section{Acknowledgements}

There are a range of people that have supported us during the project's development. Special thanks go to the reviewers of this manuscript and to the my supervisors in directing the author to be able to do research better, and be thorough so that it can benefit the community and the surrounding environment. 


\section{References}

1. R. Asnawi, Perubahan iklim dan kedaulatan pangan di Indonesia. Tinjauan produksi dan Kemiskinan, Sos. Info. 1, 3 (2015) https://doi.org/10.33007/inf.v1i3.169

2. BMKG, BMKG Digital Library (2019) https://bmkgpalangkaraya.com/doc/buletiniklim-palangkaraya.pdf

3. BNPB, BNPB Digital Library (2010) https://bnpb.go.id/buku/rencana-nasional-penanggulangan-bencana-2010-2014

4. BRIDGE, Gender and Climate Change: Mapping the Linkages a Scoping Study on Knowledge and Gaps (University of Sussex. Brighton, 2008)

5. B. Indarto, Keadilan gender dalam keadilan iklim (CSF, Jakarta, 2011).

6. S. N. A. Codjoe, L. K. Atidoh, V. Burkett, Gender and occupational perspectives on adaptation to climate extremes in the Afram Plains of Ghana, Clim. Cha. 110, 1-2 (2011) https://doi.org/10.1007/s10584-011-0237-z

7. C. Indirastuti, A. M. Pratiwi, Ketika lahan basah mongering: kajian ekologi politik feminis degradasi ekosistem gambut di Kalimantan Tengah dan Selatan, J. Perem. 24, 4 (2019) http://dx.doi.org/10.34309/jp.v24i4.379

8. S. Marlina, Kajian curah hujan untuk pemutakhiran tipe iklim beberapa wilayah di Kalimantan Tengah, Med. Ilm. Tek. Ling. 1, 2 (2016) https://doi.org/10.33084/mitl.v1i2.141

9. A.M. McCright, The effect of gender on climate change knowledge and concern in American public, Pop. Env. 32, 1 (2010) https://doi.org/10.2307/40984168

10. Mirmanto, Vegetation analyses of Sebangau peat swamp forest, Central Kalimantan, Biodiv. 11, 28 (2010) https://doi.org/10.13057/biodiv/d110206

11. D. Mulasari, Peran gender perempuan terhadap pertumbuhan ekonomi di Provinsi Jawa Tengah tahun 2008-2012, Eco. Dev. Anal. J. 4, 2 (2015) https://doi.org/10.15294/edaj.v4i3.14832

12. M. Nauly, Konflik Peran Gender pada Pria: Teori dan Pendekatan Empirik (University of North Sumatera, Medan, 2002)

13. Oluwatayo, B. Isaac, Climate change and adaptive capacity of women and water stress in urban centers of Nigeria: emerging concerns and reactions, Loc. Sustain. 1, 2 (2011)

14. M. Osaki, N. Tsuji, Tropical Peatland Ecosystems (Springer, Japan, 2016)

15. D. Rocheleau, Feminsit Political Ecology: Global Issues and Local Experiences (Routledge, New York, 1996)

16. Sugiyono, Metode Penelitian Kuantitatif Kualitatif Dan R\&D (Alfabeta, Jakarta, 2012)

17. R. Suzuki, Gender and REDD+: Bulletin REDD-net Asia Pacific (Bangkok, 2011) https://www.recoftc.org/publications/0000042

18. UNDP, UNDP Digital Library (2012) http://www.uneca.org/acpc/about_acpc/docs/UNDP-GENDERCLIMATECHANGERESOURCĒGUIDE.pdf.

19. S. R. Usop, Ruang masyarakat adat dalam pemanasan global dan perubahn iklim kasus program REDD+ di Kalimantan Tengah, Masy. Indo. 38, 1 (2012) http://jmi.ipsk.lipi.go.id/index.php/jmiipsk/article/view/295/166

20. R. Rahmawati, A. Demartoto, R. B. Soemanto, Analisis perspektif gender dalam pola perilaku purna migran perempuan di Sragen, J. Anal. Sos. 4, 2 (2017) https://doi.org/10.20961/jas.v6i2.18120 